\title{
ANKYLOSING SPONDYLITIS: A SURVEY
}

\author{
BY \\ F. DUDLEY HART \\ London
}

(RECEIVED FOR PUBLICATION JULY 2, 1954)

It is appropriate that this number of the Annals of the Rheumatic Diseases should contain a survey of the recent work on that disorder known variously as Ankylosing Spondylitis, Rheumatoid Spondylitis, Marie-Strümpell's Disease, von Bechterew's Disease or Pelvo-spondylitis Ossificans; appropriate in that few in this country have given as much time to its study and as much attention to the problems it poses as Dr. C. W. Buckley of Buxton. For the past 25 years or so he has contributed steadily to our knowledge of this disease (Buckley, 1931, 1932 $1934,1935,1936,1938$ a,b, 1940, 1943, 1945, 1948a,b). In his first communication (Buckley, 1931), he reported 150 cases of various types of spondylitis and emphasized that von Bechterew's disease and Marie-Strümpell's disease were not two separate disorders, as had been claimed, but one disorder, that known now as ankylosing spondylitis, then as spondylitis deformans. At this time he emphasized the importance of preventing hip ankylosis and spinal kyphosis. In 1943 he drew attention to a useful diagnostic feature, the absence of compensatory increase in the normal lumbar curvature in ankylosing spondylitis as compared with its presence in adolescent kyphosis, a disease with which spondylitis had previously been confused. In the light of the recent papers by Romanus (1953) and Ford (1953), it is to be noted that he made a distinction between ankylosing spondylitis and the syndrome following genito-urinary infection, stating:

If the hands or feet are affected before or simultaneously with the spine the diagnosis is not ankylosing spondylitis but infective arthritis, possibly of gonococcal origin affecting the spine (1943).

Gonorrhoeal arthritis may undoubtedly attack the spinal articulations but in such cases other joints are usually affected earlier, and the regular centrifugal progress as well as some other characters are absent (1948).

He opposed (1943) the idea that ankylosing spondylitis was merely a spinal variant of rheumatoid arthritis on the grounds of the different sex ratio, the tendency to bony ankylosis, the centrifugal spread, and the failure to respond to gold therapy Most workers in the United Kingdom still feel now as he did 10 years ago.

So many different views are still held on the nomenclature, aetiology, pathology, classification $\vec{z}$ and treatment of ankylosing spondylitis, that, even confining oneself to Great Britain, few dogmatico statements are possible. Most workers in thiso country consider ankylosing spondylitis a rheumatoid disorder, but more than a simple variant ofs rheumatoid arthritis; until more critical diagnostie tests are elaborated over the whole field of rheuma- $\frac{\Phi}{3}$ toid disease there seems little point in assuming ano identical but unknown aetiology for two disorders, $\stackrel{\Phi}{-}$ particularly when points of difference outweid $\vec{b}$ points of similarity. Buckley's four essential poirits of difference are still valid; radiological differences are obvious, and the differential sheep cell agglutiration test (Rose and others, 1948; Ball, 1952; Svartz and Schlossmann, 1950; Foz, Batalla, and Barcelo@ 1951), while giving positive results in some 40-900 per cent. of cases of rheumatoid arthritis in different series, only very rarely gives a weak positive reaction? in a true case of ankylosing spondylitis. On histological grounds Van Swaay $(1950,1951)$ considers the disorder a different one, as Forestier and others(1951) affirmed on clinical grounds in their paper presented at the European Conference on RheumaticoDisorders. This argument will continue indefinitely. until the aetiology of rheumatoid disease as a wholeo is better understood and until more exact diagnostic $₹$ criteria are evolved. In the meantime, it is, perhaps, more profitable to study these disorders as different $\$$ unsolved problems rather than to put them all into을 one diagnostic cauldron. In the study of the distinctive differences of the individual disorders more. may be learnt of rheumatoid disease as a whole.

Family History.-There has been considerable $e^{N}$ interest in the incidence of positive family histories? in this disorder. Hersh and others (1950) observed? the pattern of inheritance in fifty families and con- $\mathbb{\Phi}$ cluded that ankylosing spondylitis could be attributed ${ }^{+}$ to an autosomal dominant factor, with about 70 per $\frac{T}{0}$ 
cent. penetrance in the male and 10 per cent. in the female. Ankylosing spondylitis has been reported in two pairs of fraternal twins (Campbell, 1947; Rogoff and Freyberg, 1949) and in sisters (Fraser, 1950). Mason (1951) reported an unusual family where three members were certainly and three probably affected. Böni and Hautmann (1950), Tegner and Lloyd (1949), Blécourt (1951), and other authors comment on the familial incidence, and Parr and others (1951) recorded a significant family history in 11 per cent. of their cases.

Pathology.-Collins (1949) and Boland (1953) give what may be called the orthodox view of this disorder: an inflammatory condition of the sacroiliac joints, the apophyseal joints of the spine, and the costovertebral articulations, with infiltration of lymphocytes and plasma cells and synovial membranous proliferation, the same changes as occur in the peripheral joints in rheumatoid arthritis. Granulation tissue growing out from inflamed synovial membrane invades the articular cartilage, eroding and destroying it, and the joint space becomes filled with fibrous tissue with eventual bony fusion. Van Swaay $(1950,1951)$ points out from how relatively few papers this account has grown and on what a small amount of pathological material it is based. As a result of careful study of the vertebral columns of three cases he came to the conclusion that in the spinal articulations no synovial proliferation and no cellular infiltration or vascularization occurred. The pathological process he considered distinctive and unlike that of rheumatoid arthritis, in that the joint was obliterated by new cartilage proliferating to replace the old, all joint space being destroyed by this new growth, and calcification then occurring to give bony fusion. Cruickshank (1951) obtained material taken from hips, sternoclavicular joint, knees, and sacro-iliac joints in this condition, in nine cases at operation and in three at autopsy. He found a process similar to that seen in rheumatoid arthritis but with a greater tendency to haemorrhage, a more marked and frequent thickening of small vessels and a greater tendency to bony fusion. He did not, from the evidence of his material, think that the assumption of the unity of the two diseases was warranted on histological grounds. In this issue Engfeldt, Romanus, and Ydén (1954) report details of one autopsy and several biopsy specimens; inflammatory changes were seen in some of the biopsy material, but not in the autopsy specimen where the disease had been present for some 30 years.

Clinical Picture.-The clinical picture is suffi- ciently well known to need no fresh description, but certain small signs have been commented on and may therefore be mentioned. Tenderness over the ischial tuberosities, iliac crest, and many other bony points is a very frequent finding (Hart and others, 1949), and may even bring the patient to the clinic. This bony tenderness may persist for weeks, months, or more rarely years; one of our patients habitually carries a small cushion as a protection for his tender ischial tuberosities. This bony tenderness may need local therapy and may mislead the diagnostician, for the punched-out areas seen in $x$-ray photographs may be mistaken for tuberculous disease if in an abnormal site such as the shoulder, or the vertebral body. Involvement of the sternomanubrial joint has been described by Savill (1951), Solovay and Gardner (1951), and Françon and others (1953). Davis and Blair (1950) emphasize the frequency of calcaneal periostitis or spurs in this condition. Hart and others (1950) emphasized the frequency of intercostal respiratory restriction as a prominent and diagnostic physical sign.

As regards peripheral joint involvement, figures vary immensely in different publications, perhaps partly because of different follow-up periods. Parr, White, and Shipton (1951) noted a peripheral onset in six of one hundred cases, Kuhns (1951) in 6.5 per cent. of two hundred cases, and Hart (1954) in 24 of 184 cases (13 per cent.). Forestier and his colleagues (1949), in a review of 200 cases of ankylosing spondylitis, found that 78 per cent. of 36 female and 56 per cent. of 164 male patients had peripheral joint involvement at some stage of the disease process. Sharp and Easson (1954), in an informative and stimulating paper, noted that, of their 332 cases, 242 were considered to be typical cases of ankylosing spondylitis, 59 atypical, and 31 borderline, the atypical group showing more peripheral joint involvement and a greater incidence (12 per cent.) of the tendinitis and tendon nodules which are virtually non-existent in typical spondylitics. This group of patients with peripheral changes occurs in a greater or lesser degree in all series of cases, but appears to be more common in the United States of America than in the United Kingdom (Glyn, 1953).

Iritis and iridocyclitis appear to be relatively common in ankylosing spondylitis, Buckley (1948a) giving 10 per cent. as the approximate incidence; it is clear (Hart, 1951) that the older the group of spondylitics studied the higher the incidence will be, the number of observation years being greater. Iritis may occur during the course of the spondylitis or it may precede it (Chan and Sun, 1951). No case of scleromalacia perforans in a spondylitic has so far been published. 
Radiological Changes.- $X$-ray changes in ankylosing spondylitis are described in many publications (Scott, 1939; Forestier, 1939; Rolleston, 1947; Knutsson, 1950, 1953; Mowbray, Latner, and Middlemiss, 1949; Boland, 1953; Boland and Shebesta, 1946). There are, however, some recent observations of considerable interest. Guest and Jacobson (1951) drew attention to the lesions in bone, both extra- and intrapelvic. Oval zones of porosis, irregular bone margins with whiskery outgrowths, and occasional bitten-out areas into soft tissues, occur commonly in the pelvis on its outer aspect, but not on its inner margin which is free from muscle insertions. These authors found that $74 \cdot 4$ per cent. of the ninety patients studied had such lesions, commonly in ischial tuberosities and iliac crests. Extrapelvic lesions of this nature are not so readily recognized, and if in the vertebral body or humeral head may be mistaken for tuberculous lesions. Hamilton (1949) and Hart, Bogdanovitch, and Nichol (1950) reported on the radiological features of thoracic rigidity, the last-named using double-exposure films which showed restricted rib excursion but full or excessive diaphragmatic movement. This thoracic rigidity is a peculiar feature of ankylosing spondylitis and the double exposure film in expiration and inspiration is an easy way of demonstrating it radiologically.

Therapy.-The therapeutic pendulum has to-day swung away from emphasis on rest and fusion in a good position to a programme of much greater activity. The plaster shells and weeks or months of bed rest popular some years ago proved too productive of fixed hips and generally gave poor results (Swaim, 1939). Although many centres still use supporting jackets, many workers have largely or entirely abandoned them (Wyatt, 1945; Hart and others, 1949; Sharp and Easson, 1954) and have substituted for them exercises and postural drill. Edström (1952), for instance, advises back stretching and extension exercises thrice daily. Various forms of physiotherapy may occasionally give symptomatic ease, but they may on occasion aggravate symptoms. Manipulation has little or no part to play in therapy, for it is generally considered to be contraindicated in the treatment of spinal stiffness, and in the bed-fast osteoporotic subject fractures readily occur on manipulation of the hips.

Butazolidin (phenylbutazone) is a useful drug in ankylosing spondylitis, both in the early acutely painful phase and also later in the disease course; indeed, it is one of the most useful drugs for the fused spondylitic, who, with advanced crippling disease, still experiences much pain. Unfortunately in many cases the effective dose is also the toxic dose, and spondylitics, as a class already prone to dyspepsia and peptic ulceration (Hart and others, 1954), frequently show signs of gastric intolerance within a few days of starting the drug. Nevertheless, if it can be tolerated it is a useful analgesic and superior to simpler remedies because of its more prolonged action. Its other toxic side-effects, oedema, skinrashes, buccal mucosal ulceration, haemorrhagic diathesis, etc., are much less common, and agranulocytosis is extremely rare.

Cortisone and ACTH are both useful in the treat- $\overrightarrow{0}$ ment of acutely painful exacerbations (Hart, 1952), and cortisone is also of use in the prolonged suppressive treatment of the occasional patient who continues to deteriorate while on other therapeutic measures. Short-term hormone therapy may also be given as part of a programme of rehabilitation or to facilitate the administration of other forms of $\vec{\circ}$ treatment. West and Newns (1954) treated six 을 patients with ACTH for periods of from $1 \frac{1}{2}$ to 2 years. They concluded that prolonged adrenal os stimulation was justified only in the most severe $\frac{\mathbb{D}}{O}$ cases.

Deep $x$-ray therapy has been well discussed in excellent articles by Richmond (1951), Desmarais (1953), and Scott and Easson (1954). This form of $\overrightarrow{0}$ therapy gives more lasting results than any othes its effect lying essentially in pain relief as the rango of spinal movements is little affected in any but early cases.

Surgery.-On the whole surgery has a very $\frac{0}{\mathbb{D}}$ restricted part to play in this disease. Operations on the hip are less satisfactory than in other rheumatic $\vec{O}$ disorders, though Girdlestones or Batchelor's pseudarthrosis, or a Smith-Petersen's cup arthroplasty may help the individual carefully selected case. Revision operations are not uncommon in cup arthroplasty, but they cannot be done in the $\frac{\sigma}{\sigma}$ pseudarthroses. Lumbar wedge osteotomy is a useful operation for the severely kyphotic patient.

\section{Summary}

It is impossible to summarize this short survey. No attempt has been made to cover differential diagnosis, complications, or prognosis, nor to discuss in detail any particular aspect of the disorder. $\sigma$ An attempt has merely been made to point to certain $N$ of the more interesting recent findings and obser- N vations, and to re-emphasize the indebtedness of all $\sigma$ of us to that pioneer in this field of study, Dr. C. W. Buckley.

Ball, J. (1952). Annals of the Rheumatic Diseases, 11, 97 Blécourt, J. J. de (1951). Ned. T. Geneesk., 95, 3763.

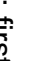


Boland, E. W. (1953). In "Comroe's Arthritis", p. 551, 5th ed., ed. J. L. Hollander. Kimpton, London.

- and Shebesta, E. M. (1946). Radiology, 47, 551.

Böni, A. and Hautmann, F. (1950). Z. Rheumaforsch., 9, 273.

Buckley, C. W. (1931). Brit. med. J., 1, 1108.

- (1932). Proc. roy. Soc. Med., 26, 105.

- (1934). Lancet, $2,246$.

- (1935). Rep. chronic Rheum. Dis., 1, 77.

(1936). "The British Encyclopaedia of Medical Practice", vol. 2, p. 105, ed. H. Rolleston. Butterworth, London. (1938a). "Arthritis, Fibrositis and Gout", p. 85. Lewis,

London. In "A Survey of Chronic Rheumatic Diseases", p. 171,
(1938b). In ed. R. G. Gordon, G. P. R. Aldred-Brown, J. B. Burt, F. J. Poynton, R. Waterhouse, and G. D. Kersley. Oxford University Press, London.

(1940). Annals of the Rheumatic Diseases, 2, 83.

(1943). Brit. med. J., 2, 4.

(1945). Annals of the Rheumatic Diseases, 5, 49.

1948a). In "Textbook of the Rheumatic Diseases", p. 234,

(1948). Annals of the Rheumatic Diseases, 7, 17

Campbell, A. M. G. (1947). Lancet, 1, 406.

Chan, E., and Sun, S. F. (1951). Chin. med. J., 69, 147.

Collins, D. H. (1949). "The Pathology of Articular and Spinal Diseases", p. 313. Arnold, London.

Cruickshank, B.'(1951). Annals of the Rheumatic Diseases, 10, 393.

Davis, J. B., and Blair, H. C. (1950). J. Bone Jt Surg., 32A, 838.

Desmarais, M. H. L. (1953). Annals of the Rheumatic Diseases, 12,25

Edström, F. (1952). Acta med. scand., 142, 11.

Engfeldt, B., Romanus, R., and Ydén, S. (1954). Annals of the Rheumatic Diseases, 13, 219.

Ford, D. K. (1953). Ibid., 12, 177

Forestier, J. (1939). Radiology, 33, 389.

- Jacqueline, F., and Bews, A. (1951). "Comunicaciones. 2 Congreso Europeo de Reumatologia, Barcelona”, p. 10. Editorial Scientia, Barcelona.

Foz, A., Batalla, E., and Barceló, P. (1951). "Comunicaciones. 2 Congreso Europeo de Reumatologia, Barcelona", p. 530.

Françon, F., Faidherbe, P., du Lac, G., and Leblanc, G. (1953). Presse Med., 61, 109.

Fraser, T. N. (1950). Annals of the Rheumatic Diseases, 9, 231.

Glyn, J. H. (1953). "West London Hospital, Department of Rheumatic Diseases Annual Report", Annals of the Rheumatic Diseases, 13, 252. Guest, C. M., and Jacobson, H. G. (1951). Amer. J. Roentgen., 65,

Hamilton, K. A. (1949). Ann. intern. Med., 31, 216.

Hart, F. Dudley (1951). Trans. ophthal. Soc. U.K., 71, 167.

- (1952). Brit. med. J., 1, 188

(1952). Brit. med. J.

Bogdanovitch, A., and Nichol, W. D. (1950). Annals of the Rheumatic Diseases, 9, 116.

- Robinson, K. C., Allchin, F. M., and Maclagan, N. F. (1949). Quart. J. Med., 18, 217.

Hersh, A. H., Stecher, R. M., Solomon, W. M., Wolpaw, R., and Hauser, H. (1950). Amer. J. hum. Genet., 2, 391.

Knutsson, F. (1950). Acta radiol., 33, 557.

(1953). "Modern Trends in Diagnostic Radiology", 2nd series, p. 267, ed. J. W. McLaren. Butterworth, London.

Kuhns, J. G. (1951). Stetoscopio, 1, 31.

Mason, R. M. (1951). Annals of the Rheumatic Diseases, 10, 78.

Mowbray, R., Latner, A. L., and Middlemiss, J. H. (1949), Quart. J. Med., 18, 187 .

Parr, L. J. A., White, P., and Shipton, E. (1951). Med. J. Aust., $1,544$.

Richmond, J. J. (1951). Proc. roy. Soc. Med., 44, 443.

Rogoff, B., and Freyberg, R. H. (1949). Annals of the Rheumatic Diseases, 8, 139.

Rolleston, G. L. (1947). Brit. J. Radiol., 20, 288.

Romanus, R. (1953). "Pelvo-spondylitis ossificans in the male and genito-urinary infection", Acta med. scand., Suppl. 280.

Rose, H. M., Ragan, C., Pearce, E., and Lipman, M. O. (1948). Proc. Soc. Exp. Biol., 68, 1 .

Savill, D. L. (1951). J. Bone Jt Surg., 33B, 56.

Scott, S. G. (1939). "Wide-Field X-Ray Treatment". Newnes, London.

Sharp, J., and Easson, E. C. (1954). Brit. med. J., 1, 619.

Solovay, J., and Gardner, C. (1951). Amer. J. Roentgen., 65, 749.

Svartz, N., and Schlossmann, K. (1950). Annals of the Rheumatic Diseases, 9, 377.

Swaim, L. T. (1939). J. Bone Jt Surg., 21, 983.

Tegner, W., and Lloyd, K. (1949). Lancet, 2, 196.

Van Swaay, H. (1950). "Spondylosis Ankylopoetica". Edward Ijdo, Leiden.

- (1951). "Comunicaciones. 2 Congreso Europeo de Reumatologia, Barcelona", p. 99.

West, H. F., and Newns, G. R. (1954). Annals of the Rheumatic Diseases, 13, 109.

Wyatt, H. (1945). Brit. J. Radiol., 18, 301. 